\title{
EFFECT OF MOWING ON THE STRUCTURE OF SEDGE COMMUNITIES IN THE CHWISZCZEJ RIVER VALLEY (BIAŁOWIEŻA FOREST)
}

\author{
AleKsander Kołos \\ Białystok Technical University, Institute of Environmental Engineering and Environmental Protection, Poland \\ Manuscript Received: April 11, 2011 \\ Revised Version: March 15, 2012
}

KoŁos A., Effect of mowing on the structure of sedge communities in the Chwiszczej River valley (Białowieża Forest). Quaestiones Geographicae 31(3), Bogucki Wydawnictwo Naukowe, Poznań 2012, pp. 33-39. 7 Figs. DOI 10.2478/v10117-012-0009-5, ISSN 0137-477X.

AвSTRACт. The paper presents the results of the 4-year studies on the influence of mowing on sedge communities structure in the near-edge zone and in the riverbed-adjacent zone of the Chwiszczej River valley (Białowieża Forest). It was assumed that various habitat conditions in different parts of the valley could modify effects of mowing. The floristic richness of sedge dominated patches increases under the influence of mowing in both zones of the valley, mainly as a result of growing number of meadow species. These changes are determined by habitat factors only in the central part of the valley, where ground water's dynamics is the biggest. Effects of mowing are almost completely canceled by long-lasting flooding. Such flooding may affect on sedge communities' structure stronger than mowing. Irrespective of local habitat conditions, mowing is favorable to spread of Calamagrostis stricta, which is species of high competitiveness. Its domination could lead to decrease of floristic richness in rush communities.

KEY WORDS: mowing, sedge communities, wetland management, Calamagrostis stricta

Aleksander Kołos, Institute of Environmental Engineering and Environmental Protection, Biatystok Technical University, ul. Wiejska 45E, 15-351 Biatystok, Poland, e-mail: a.kolos@pb.edu.pl

\section{Introduction}

Mowing is considered one of basic methods of protecting non-forest ecosystems. It is applied mainly for suppressing the expansion of trees and shrubs to open plant communities. Positive influence of mowing on floristic richness of grassland and rush communities was proved in many experiments (Maron \& Jefferies 2001, Jantunen 2003, Güsewell \& Le Nédic 2004). Regular removal of aboveground biomass weakens competitive features of clonal plants and reduce necromass layer (Thomas et al. 2005). Many herba- ceous species, previously limited by dominating grasses and sedges, found convenient conditions of growth in such circumstances. Thus, mowing as one of the most common anthropogenic disturbance in natural environment moulds directly inner structure and physiognomy of non-forest communities.

The peat-covered river valleys on the lowland of Poland are usually overgrown by rushes of various kinds. Abandonment of management, especially at marshes with disturbed water relations has its effects in violent process of secondary succession and leads to crucial transformations of landscapes (Tomaszewska 1997, Kołos 
\& Próchnicki 2004). The restoration of mowing prevents those processes admittedly but at the same time causes significant changes in species composition and structure of sedge associations. Long-lasting mowing can even lead to transformation of sedge communities into meadow communities (Kołos 1991).

The aim of present research was to determine the effectivity of mowing done on the sedge dominated sites with reference to transverse zonality of river valley. It was assumed that the intensity of changes caused by mowing could be determined by diverse habitat conditions prevailing in various parts of river valley.

\section{Research area}

Chwiszczej is a small river situated in the south - west foreland of the Białowieża Forest (Fig. 1). The springs are located few kilometres west from Hajnówka near Nowe Berezowo village. The entire length of the river is $13 \mathrm{~km}$. The catchment area comes to $35,5 \mathrm{~km}^{2}$. Precipitation in a water year is assessed at $613,3 \mathrm{~mm}$ whereas in a summer half-year (May to October) - at 381,3 $\mathrm{mm}$ (Tyszka 2008). The valley is relatively narrow and agriculturally managed in the upper river course, what has an influence on the quality of water in the basin (Niczyporuk \& Wiater 2006). From Orzeszkowo locality the valley spreads

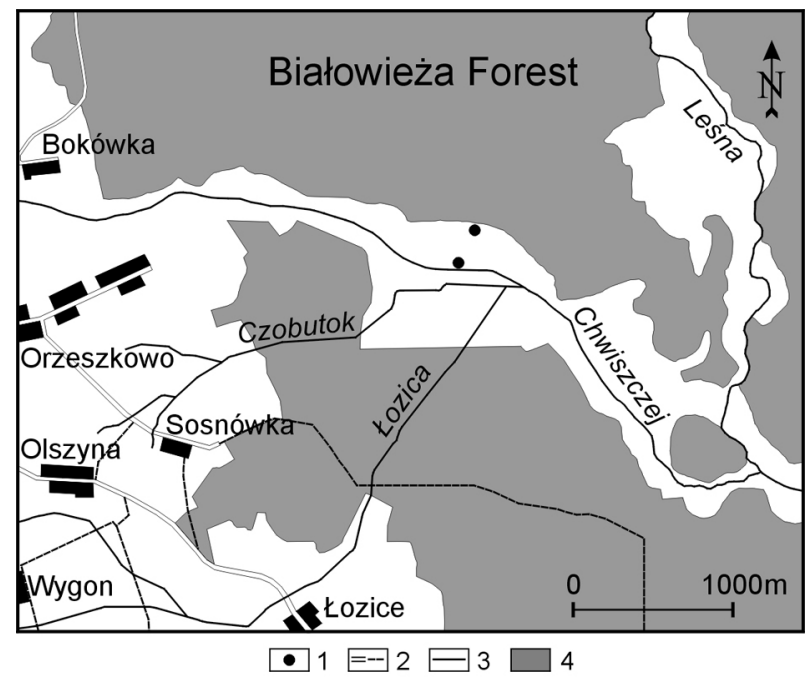

Fig. 1. Location of the study site on the basis of topographic map at 1:50,000 scale (1983).

1 - investigation plots, 2 - roads, 3 - rivers and drainage ditches, 4 - forests. and changes its type into swampy. At this segment of the valley Chwiszczej is supplied by two small streams: Czobutok and Łozica. The valley is almost flat there, with height difference lower than $0,5 \mathrm{~m}$. It is occupied by sedge communities (Magnocaricion), rush communities (Phragmition), megaforbs communities (Filipendulion), grey willow shrubs Salicetum pentandro - cinereae and boggy-alder forests as well. The terrain around Chwiszczej's confluence with Leśna River is the swampiest and the most natural.

The decision about melioration of the valley and river regulation was taken in the middle of previous century. River-control works were finished at the end of 60 . Hydrotechnical works had lead to considerable groundwater lowering in whole valley. During the next twenty years most of the organic soils had been seriously overdried. At the time local farmers had begun to limit mowing of grasslands and rushes. The last harvesting in the area was executed at the beginning of 80 . In 1991 renaturation works, which had its main aim in uplifting the groundwater level, were carried out (Domaszewicz 1995). Eventually, they surveyed only the very small fragment of the valley set in the upper river course. In 2003 the major part of the valley was included into the nature reserve. This article is based on a research done in the central part of the area, within lesser pond sedge community (Caricetum acutiformis). It is one of the most prevalent plant communities in the valley.

\section{Methods}

The researches were done on two experimental plots (mown annually) and two equivalent control plots (not mown). Each of them had the shape of 10 meters-long square, divided on four 5 meters-long squares. The one pair of investigation areas was placed near the riverbed whilst the other - in the near-edge zone of the valley. The experimental plots were mown each year in July, with usage of hand scythe. The cut biomass was removed from areas. First mowing was executed in 2006. The groundwater level was monitored in both areas, from May to November. Measurements were carried out once a month in the two wells placed nearby quadrates. Simultaneously, 
the samples of ground water were taken for electrolytic conductance determination. The changes of floristic composition of plant associations caused by mowing were documented by relevé in compliance with Braun-Blanquet scale. Phytosociological records were taken on every small square (with area of $25 \mathrm{~m}^{2}$ ) right before mowing. Before carrying out a research, the distribution of main structure-building species was mapped in 1:20 scale, right in the 3 meters-long squares, which were previously demarcated inside all of the plots. Mapping was repeated in the third field season. GeoMedia Proffesional 5.2 software was used during data analysis. Changes in species richness, groundwater level and electrolytic conductivity were tested for significance with MannWhitney test in Statistica 8.

\section{Results}

\subsection{Diversity of habitat conditions}

The soil conditions in both examined zones of the valley differ remarkably. In the near-edge zone the organic deposit reaches only about $0,5 \mathrm{~m}$ thickness whereas in the middle zone it is thrice deeper (Fig. 2). Admittedly, there is the same sort of peat that dominates in the zones (sedge peat) but in vicinity of the riverbed the upper layer (which is $25 \mathrm{~cm}$ thick) is strongly dried and consists of muck.

Substantial differences $(p<0,05)$ were also emphasised in dynamics of ground waters in both zones of the valley. In 2007 the groundwater level was relatively stable, although during growing season water in peripheral parts of the valley had subsisted over ground surface, whilst nearby riverbed - only several centimeters under the soil surface (Fig. 3). In the next two years the considerable dynamics of groundwater table was observed. In 2008 the significant water shortage was noticed in the whole valley. August and September were record-breaking in this respect water in the near-edge zone lied at $47 \mathrm{~cm}$ depth at the time. On the other hand, in the middle zone of the valley it was not detected until $55 \mathrm{~cm}$ depth. Next season, however, was absolutely different - the spring flooding took whole valley and remained there till the end of July $(40-45 \mathrm{~cm}$ over

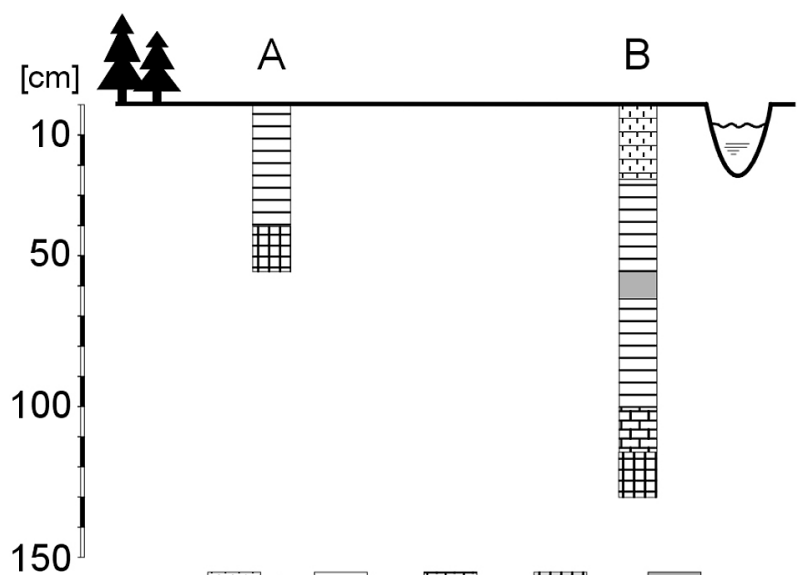

30

Fig. 2. Structure of organic deposit in marginal zone (A) and central zone (B) of the Chwiszczej river valley. 1 - muck, 2 - moderately decomposed sedge peat, 3 - well-decomposed sedge peat, 4 - sanded peat, 5 - sedge-alder peat.

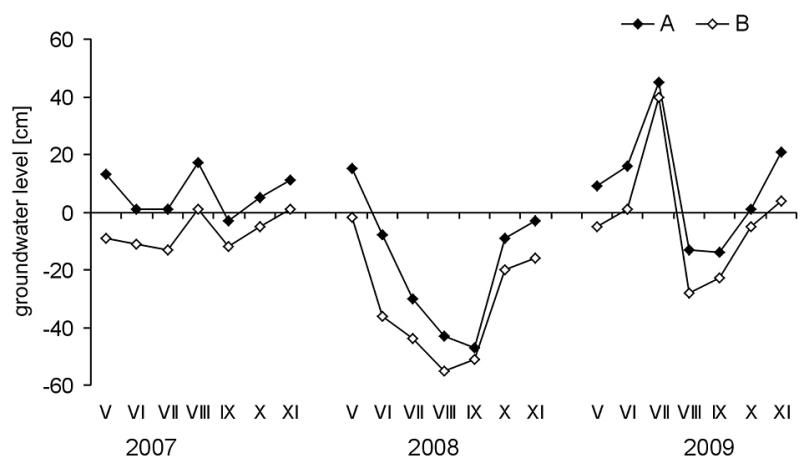

Fig. 3. Changes of groundwater level in near-edge zone (A) and near-bed zone (B) of the Chwiszczej river valley in the years 2007-2009.

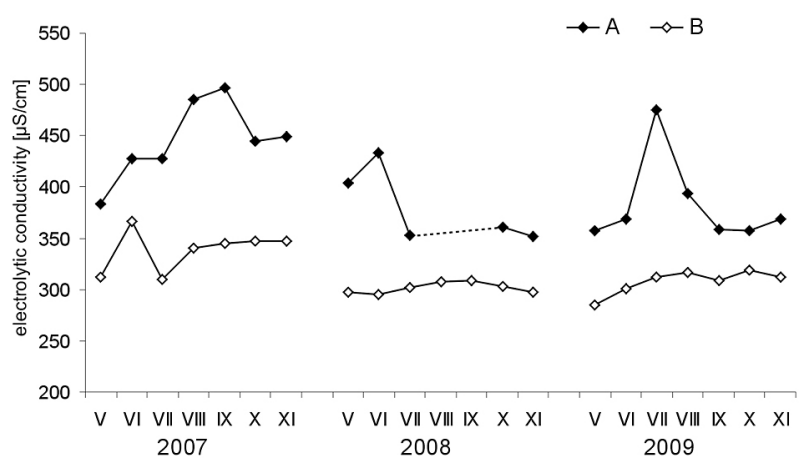

Fig. 4. Changes of groundwater electrolytic conductivity in marginal zone (A) and bed-adjacent zone (B) of the Chwiszczej river valley in the years 2007-2009.

ground level). In the next month, water suddenly decreased to 13-28 cm under ground surface and remained in this way thorough the rest of the vegetative season (Fig. 3). The largest differences 
between groundwater levels in both zones were observed at the beginning of the season (up to 22 $\mathrm{cm})$.

It was claimed that the habitat in the central part of the valley was less rich in nutrients than this situated in the near-edge zone, affirmed by $30 \%$-lower conductivity of ground water (Fig. 4). Bigger fluctuations of this parameter were observed in case of samples collected in the vicinity of the valley's edge.

\subsection{Changes of floristic richness}

The number of species on investigation plots has risen under the influence of mowing during next years (Fig. 5). The biggest floristic richness was noted after second mowing: 5 species appeared on area near riverbed (growth by 26\%) and 8 species appeared on area nearby valley's edge (growth by 38\%). After the next mowing the number of species on both plots suddenly decreased to level marked at the beginning of investigation. In the unmown quadrates the number of species has shown slight downward tendency in four years. Changes of floristic richness caused by mowing are dependent on average level of ground waters only on quadrates situated in the middle part of the valley ( $\left.p<0,05, R^{2}=99 \%\right)$. Significant relation between floristic richness and electrolytic conductance of ground water was not detected.

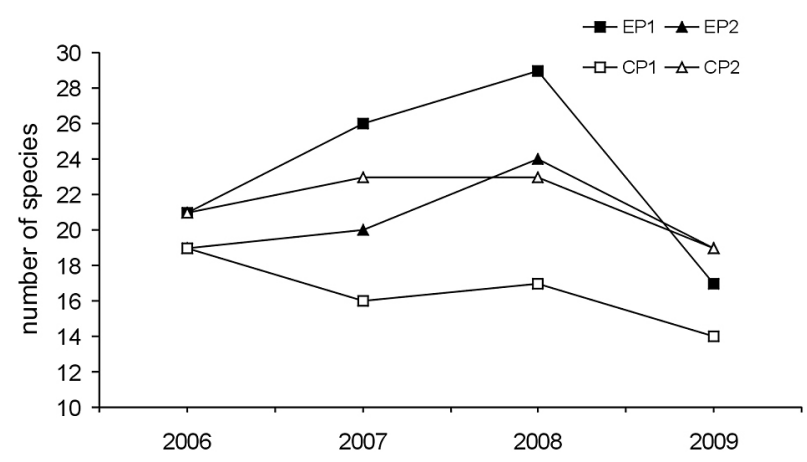

Fig. 5. Changes of floristic richness of sedge dominated patches caused by yearly mowing in different parts of the Chwiszczej river valley. EP1/CP1 - experimental/control plots in marginal zone, EP2/CP2 - experimental/control plots in riverbed-adjacent zone.

\subsection{Changes in structure of plant associations}

Sedge dominated patches situated close to valley's margin had simplified structure before carrying out a study. They were dominated by sedges (Carex acutiformis, C. acuta, C. vesicaria), which formed homogenous patches with sporadic occurrence of herbaceous plants. In that part of the valley, where soil was well watered, significant changes in inner structure of patches were not noticed even after triple mowing (Fig. 6.) On the other hand, sedge associations that occupied overdried muck soil nearby riverbed had completely different structure: they were enriched by numerous meadow- and macroforbes species (Lysimachia vulgaris, Lythrum salicaria, Stachys palustris, Lychnis flos-cuculi, Filipendula ulmaria and others). Locally, they reached the status of codominant species. Under the influence of annual mowing the cover of species has increased. However, as a result of high surface flooding, which occurred in Chwiszczej river valley in 2009, herbaceous species have evidently reduced their presence on investigation plots. Those changes revealed themselves most distinctly in case of Lysimachia vulgaris and Stachys palustris.

Mowing turned out as a favourable to spreading of some plants with iterative type of growth. One of them is evidently reed grass Calamagrostis stricta. The growing importance of the species in sedge-dominated patches was spotted on both investigation surfaces (Fig. 7). The cover of Calamagrostis stricta on the plot situated in the central part of valley has increased by $57 \%$ whereas in the area settled in the marginal zone it has increased five times. Comparatively, on the unmown quadrates the decrease of that species' cover was marked.

\section{Discussion}

The flora of the Chwiszczej River valley was formed by floodings and extensive land-use practices. Melioration and regulation of the riverbed caused modification of water relations, vegetation and flora almost in the whole valley. The landscape of the valley has changed as a result of abandonment of management. After a few dozen 


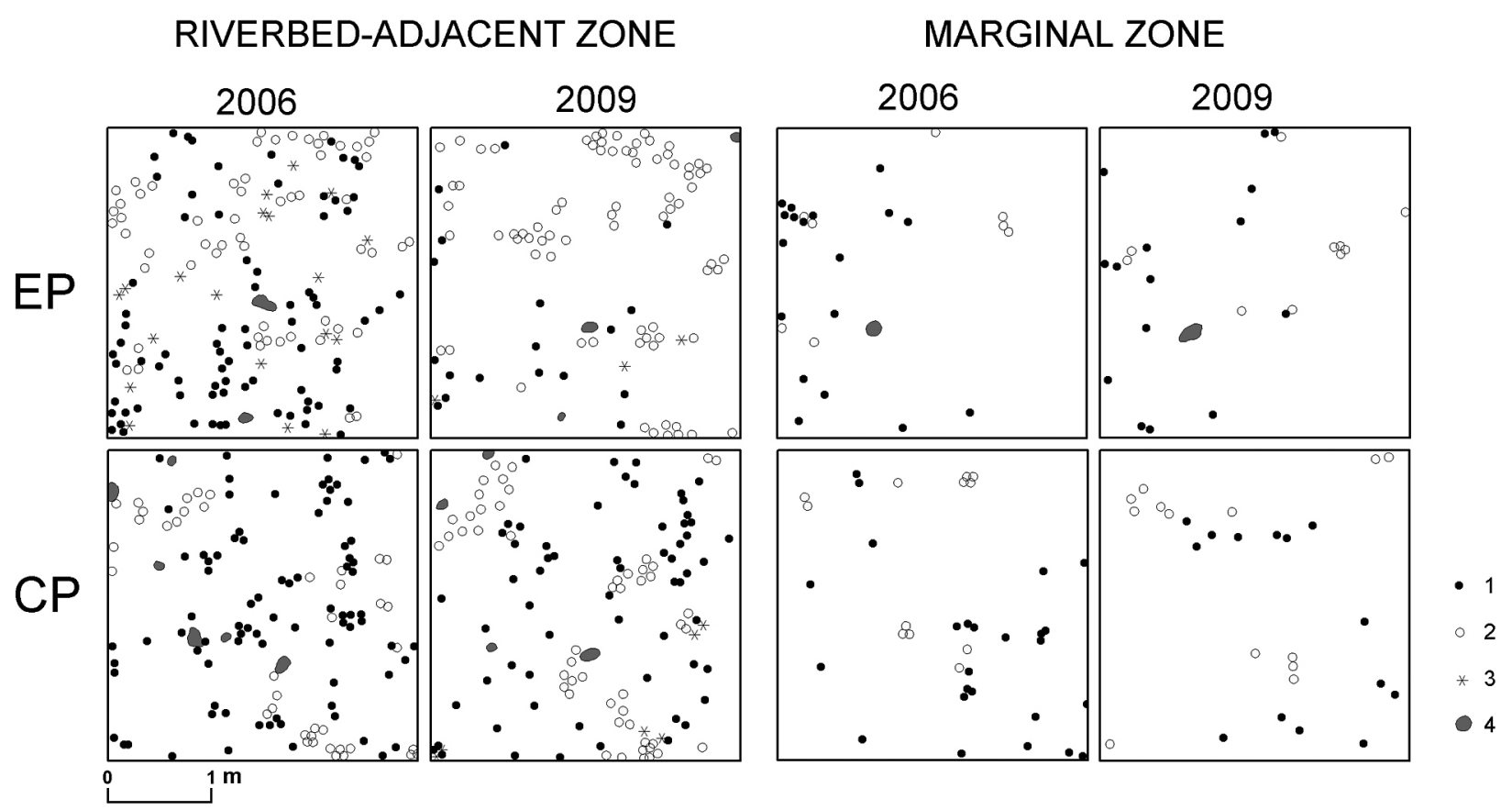

Fig. 6. Influence of 3 years mowing on wet meadow species occurrence in sedge communities in different parts of the Chwiszczej river valley. Distribution of aboveground shoots of Lysimachia vulgaris (1), Lythrum salicaria (2), Stachys palustris (3) and Filipendula ulmaria (4) on mown (EP) and unmown (CP) quadrates is presented in the maps.

years disturbances show off in the central part of the valley, where ground is overdried every year as a consequence of faster flow. In the marginal zone the changes are less noticeable due to constant supply of soligenic waters, which supports ground's irrigation. Suppositions claiming that mowing of rush communities in the different parts of the valley would have a distinct effect were only partly confirmed.

It was claimed that floristic richness on both experimental quadrates was growing initially under the influence of mowing. The growth was slightly bigger on the plots situated in the border area. Annual removal of biomass was favourable to growth of plants, which are characteristic for wet meadows (Myosotis palustris, Crepis paludosa, Galium uliginosum, Poa palustris). They appeared probably thanks to numerous exposed microhabitats. As it was proved earlier, annual removal of aboveground biomass induces formation of such areas (Parr \& Way 1988) and seeds of those species, which growth was limited by clonal plants, have bigger chance to germinate (Foster \& Gross 1998, Berendsee 1999, Lepš 1999). However, after three years of permanent mowing the majority of "new" species have retreated from both plots. The decrease of species was also observed on the control quadrates. This phenomenon could be interchangeably linked with intensive and long-lasting inundation, which occurred in the valley in June and July 2009. One could have an
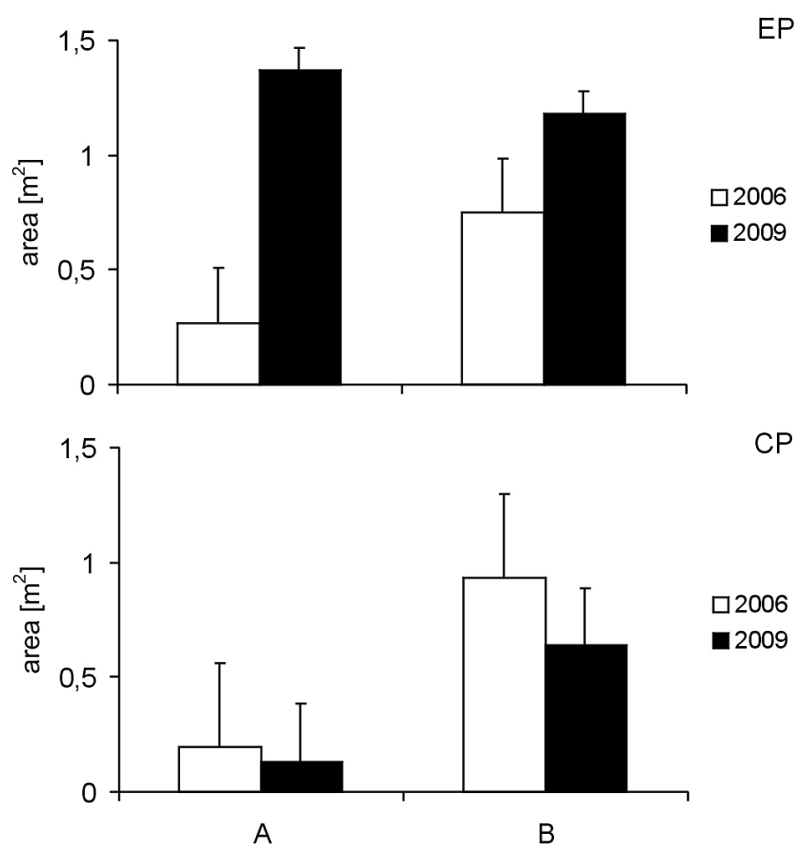

Fig. 7. Influence of mowing on Calamagrostis stricta dispersal in sedge communities overgrowing marginal zone (A) and riverbed-adjacent zone (B) of the Chwiszczej river valley. EP - experimental plots (mown), CP - control plots (unmown). 
impression that floristic status of mown patches was "reset" by a high level of surface water. Numerous wet meadow herbs tend to grow in habitats where water table reaches at most a few centimetres above the soil surface level, so that they cannot survive such deep and long-lasting inundation. It could be claimed that flooding has much bigger impact on species composition and durability of rush communities than mowing. The fluctuations of groundwater level are recognized as one of the most important factor modifying flora and vegetation of hydrogenic habitats (Laitinen et al. 2007, Xu et al. 2007).

During the first years of mowing the inner structure of sedge communities changed in a marginal degree, regardless of which part of the valley they were situated in. More significant transformations could be observed only after long-lasting use of that factor. It was claimed, that mowing is favourable to growth of those species, which can modify community structure radically, especially to some clonal plants, inter alia grasses (Stampfli \& Zeiter 1999). According to investigations done in the Narewka River valley in the Białowieża Forest, annual mowing effectively eliminates lesser pond-sedge Carex acutiformis, but after 8-10 years it is replaced by other clonal species, such as Phragmites australis and Calamagrostis stricta (Kołos, unpublished data). Investigations carried out in the Chwiszczej River valley confirm these observations. Mowing is a factor that stimulates spread of Calamagrostis stricta irrespective of local habitat and hydrological conditions. The increase of this species' cover was marked after mowing the quadrates situated both in the central and in the marginal zone of the valley. It seems that slimstem reedgrass could be as competitive to other plants as Phragmites australis (Güsewell et al. 2000) and Phalaris arundinacea (Kennedy et al. 2003). The spread of slimstem reedgrass was not moderate even by long-lasting flooding in 2009. Domination of this species in plant communities could lead to decrease of floristic diversity, for Calamagrostis stricta tends to form very compact aggregations, where only few plants can survive.

As the results show mowing during the first years causes some changes in the structure of sedge communities. However, their stability is strongly dependent on weather and habitat fac- tors. Carex acutiformis dominated sites, which could be found in the central part of the valley, differ remarkably from those occurring on its near-edge zone. Mowing consolidates the differences, but only to a certain degree. During inundations the effects of mowing are levelled. The crucial role of abiotic factor in modification of species composition in mown plant communities was mentioned previously by Huhta (2001) and Schaffers (2002). Such conclusions indirectly have their confirmation in relationship between floristic richness of sedge-dominated patches in the Chwiszczej River valley and ground water level in the central part of the valley. These relations were not marked in the marginal zone of the valley, where hydrological conditions are relatively stable.

Maintaining open wetland ecosystems is one of the prior aims of Polish national parks and preserves nowadays. However, the issues presented in this paper are not taken into consideration in the protective projects. The protection of rushes cannot be confined solely to regular mowing. Such communities could exist in landscapes of river valleys thanks to stabilisation of water conditions. It seems that mowing of sedge communities with omission of hydrotechnical works (which restore irrigation of wetlands) is a shortcut in realisation of protection projects.

\section{Acknowledgment}

I thank Dr Piotr Kondratiuk for help in data collection and analyses. Thanks are also due to my wife Helena and my son Mateusz for help in field works. Financial support was provided by Technical University of Białystok (grant W/ WBiIŚ/24/07).

\section{References}

BERENDSE F., 1999. Implications of increased litter production for plant biodiversity. Trends Ecol. Evol., 14: 4-5.

Domaszewicz A., 1995. Short-eared owl Asio flammeus in Poland - distribution and protection. Chrońmy Przyr. Ojcz., 51, 2: 40-50.

Foster B.L. \& Gross K.L., 1998. Species richness in a successional grassland: effects of nitrogen enrichment and plant litter. Ecology, 79: 2593-2602. 
Güsewell S. \& LE NéDiC C., 2004. Effects of winter mowing on vegetation succession in a lakeshore fen. Applied Veg. Sci., 7: 41-48.

Güsewell S., Le Nédic C. \& Buttler A., 2000. Dynamics of common reed (Phragmites australis Trin.) in Swiss fens with different management. Wetlands Ecol. Manage., 8: 375-389.

HuHTA A.P., 2001. Restorative mowing on semi-natural grasslands: community-level changes and species-level responses. Oulu Univ. Press.

JANTUNEN J., 2003. Vegetation changes in a semi-natural grassland during mowing and grazing periods. Ann. Bot. Fennici, 40: 255-263.

Kennedy M.P., Milne J.M. \& Murphy K.J., 2003. Experimental growth responses to groundwater level variation and competition in five British wetland plant species. Wetlands Ecol. Manage., 11: 383-396.

KoŁos A., 1991. Influence of the forest vicinity on the course of succession in abandoned meadows in the Narewka River valley. Phytocoenosis, 3, 1: 119-126.

KoŁos A. \& Próchnicki P., 2004. Application of retrospective analysis of aerial image to planning of re-naturalization procedures in the Wizna peat bog (Narew River Valley). Teledetekcja Środowiska, 33: 35-44.

Laitinen J., Rehell S. \& OKSAnen J., 2008. Community and species responses to water level fluctuations with reference to soil layers in different habitats of mid-boreal mire complexes. Plant Ecol., 194: 17-36.

LEPŠ J., 1999. Nutrient status, disturbance and competition: an experimental test of relationships in a wet meadow. J. Veg. Sci., 10: 219-230.
MARON J.L. \& JeFFERIES R.L., 2001. Restoring enriched grasslands: effects of mowing on species richness, productivity and nitrogen retention. Ecol. Appl., 11, 4: 1088-1100.

Niczyporuk A. \& WiATER J., 2006. The influence of basin use of Chwiszcza and Perebel River on seasonal quality of discharge water. Pol. J. Envir. Stud., 15, 5D: 397-400.

PARR T.W. \& WAY J.M., 1988. Management of roadside vegetation: the long-term effects of cutting. J. Appl. Ecol., 25: 1073-1087.

SCHAFFERS A.P., 2002. Soil, biomass and management of seminatural vegetation. P. II. Factors controlling species diversity. Plant Ecol., 158: 247-268.

Stampfli A. \& Zeiter M., 1999. Plant species decline due to abandonment of meadows cannot be reversed by mowing. A case study from the southern Alps. J. Veg. Sci., 10: 151-164.

Thomas S., THOmpson S.D. \& PALmer M.W., 2005. The effect of mowing on species richness, turnover and species composition of an Oklahoma grassland. Botany Conference, August 13-17, 2005, Austin, Texas.

TOMASZEWSKA K., 1997. The succession of willow-birch shrub as an effect of the stopping of mowing the swamps in the Biebrza valley. Przeglad Przyrodniczy, 8, 1/2: 115-120.

TYSZKA J., 2008. Hydrologic functions of forests in small lowland catchments. Instytut Badawczy Leśnictwa, Sękocin Stary.

Xu H., YE M. \& LI J., 2007. Changes in groundwater levels and the response of natural vegetation to transfer of water to the lower reaches of the Tarim River. J. Environ. Sci., 19: 1199-1207. 